\title{
Imperial Eyes. Travel Writing and Transculturation
}

El viaje, esa metáfora conceptual que admite como ninguna todas las modalidades verbales, ha sido para México acta de constitución. Desde las migraciones norteñas a Mesoamérica, de Aztlán a Tenochtitlán, a la llegada de Cortés a las costas de Veracruz, el viaje en oleadas sucesivas fundó y refundó el acta de nacimiento del México que ahora conocemos. La primera obra escrita en castellano -que originó la literatura mexicanafue una crónica de viaje, las Cartas de Relación de Hernán Cortés, donde el conquistador intentaba explicar al rey de España las maravillas de las tierras por él descubiertas: una y otra vez declaraba no tener palabras para describir los portentos vistos. Trescientos años después otro viajero - prusiano en este caso- escribió la obra que daría a conocer al mundo las riquezas con que contaba la Nueva España, así como su grado de avance y civilización. El Ensayo político del reino de la Nueva España de Alexander von Humboldt fue el libro de cabecera de todos los numerosos viajeros que en el

- Mary Louise Pratt, Imperial Eyes. Travel Writing and Transculturation, Routledge, Londres/Nueva York, 2000. siglo XIX pisaron suelo mexicano, para conocer las riquezas y oportunidades que el joven país ofrecía a la inversión extranjera.

Pero los viajeros en México fueron parte del gran movimiento de descubrimiento, coloniaje y dominación que signó el imperial siglo XIX. Los viajeros se lanzaron a los confines de un mundo que estaba redefiniendo sus límites y pertenencias. Eran la avanzada del imperio, informantes especializados que daban cuenta de rutas, caminos, climas, nativos susceptibles de "civilizar" y recursos a explorar y explotar. El conjunto de tales obras amplió la perspectiva de mundo con el conocimiento y dominio de los continentes asiático, africano y americano por las potencias imperiales, comandadas por Inglaterra, la pérfida Albión que en ese siglo creó el imperio más grande de Occidente.

Los relatos de viajeros elaboraron concepciones diferenciadas de las metrópolis imperiales (Inglaterra, Francia, Bélgica, Holanda) y de lo que se llamó "el resto del mundo". Ese "otro mundo" se representaba, significaba y resignificaba con una perspectiva eurocéntrica, que se apropiaba de las realidades coloniales, 
simbólica y materialmente: seres de color y fisonomía diferentes, con usos y relaciones sociales y naturales distintas a las metropolitanas. Paisajes, animales, plantas y minerales que ampliaron la ciencia europea y dinamizaron su economía imperial. Saber es poder. Al conocimiento de las colonias se unió la expoliación de las mismas.

Viajes al corazón de las tinieblas africanas, viajes a los centros de la sensibilidad y la racionalidad eurocéntricas que se impusieron a pueblos sometidos y explotados, pero que también se conformaron y explicaron gracias a ellos. Esa fascinante dialéctica entre el imperialista abrumado $y$ fascinado por su colonia, y el colonizado que cura, alimenta, transporta y enseña al colonizador habilidades para sobrevivir entre la selva y el desierto, pero que es definido por éste como ignorante, indolente, salvaje, inculto u holgazán. Un ser temible y despreciable a un tiempo, al que hay que dominar, civilizar, controlar y resignificar. Describir en los relatos; ficcionar en las novelas; pintar en los lienzos.

Esa compleja relación política, económica e ideológica que supuso la glosa del imperio, indispensable para su expansion y permanencia, es tratada por Mary Louise Pratt con gran maestría y erudición en Ojos Imperiales. La autora analiza los relatos de viajeros y la literatura de viajes in extenso desde fines del siglo XVIII, focalizándose en el siglo XIX y con extensiones simbólicas hasta 1980, cuando todavía se pueden apreciar, según la autora, restos de la "Estilística imperial". La elección geográfica recupera las narraciones que sobre África y Sudamérica se escribieron copiosamente en el siglo imperial, atendiendo al sentido construido en el texto por el europeo viajante, así como a los sentidos y significaciones que los "nativos" africanos y sudamericanos poseían de su propia realidad.

Una obra como Ojos Imperiales se ubica en la rica intersección de campos de los estudios culturales, el análisis literario y de género, cuyas herramientas son puestas en acción para analizar la literatura de viajes en el siglo XIX. Una de sus mayores virtudes es que exhibe una perspectiva $y$ análisis amplios y constantes, que sale de los textos que aborda para comprenderlos dentro la compleja dinámica sociohistórica del imperialismo decimonónico. Pocos son los estudiosos que analizan los relatos de viaje de esta forma: en general se limitan a hurgar en el universo de significación que cada una de las obras construye en su interior, en los límites seguros del texto.

Mary Louise Pratt estudia la mirada imperial principal pero no 
únicamente en los textos de viajes. Los estudia en el contexto problemático del imperialismo europeo que sojuzgó África, Asia y América, que impuso sobre dichas colonias maneras de hacer y ver, pero que a su vez recibió de ellas muchísimos elementos culturales que se reelaboraron en la metrópoli, de forma similar a como pasó en las colonias, donde los contenidos e imposiciones culturales del centro se reelaboraban y transformaban. A esa compleja realidad sociocultural alude el subtítulo de la obra: Relatos de viaje y transculturación; éste último término, acuñado en 1940 por el sociólogo cubano Fernando Ortiz, sustituye con éxito los conceptos de fuerte contenido político "aculturización" y "deculturizacion", que contemplan el movimiento cultural de forma reductiva y unidireccional, en el sentido impuesto por los intereses del grupo dominante.

La importancia de las construcciones sociopolíticas y culturales que realizaron los viajeros (que en muchos casos calificaron lo diferente como inferior, respecto de la pauta europea) hace necesaria la lectura de un texto como Ojos Imperiales, obra profunda que contribuye a clarificar una parte de nuestra experiencia histórica reciente, mediante un trabajo pulido y decantado, que la autora viene pensado desde hace más de veinte años.
Una muestra más de la actualidad del colonialismo intelectual que la autora analiza en el siglo XIX, es el hecho de que tales temas $y$ problemas de investigación no se investigan y difunden ampliamente en nuestro país, y en particular en el estado de Veracruz - por siglos puerta de entrada al país y lugar de paso obligado de todo viajero-, donde los relatos de viajeros - han sido ampliamente usados como fuente historiográfica. Además de ello, está el problema material de carecer de tales obras traducidas. Por ejemplo, la obra de Pratt fue publicada por vez primera en inglés en Nueva York y Londres en 1992. A partir de entonces se ha reimpreso seis veces. La Universidad de Quilmes (Argentina) lo publicó en español en 1997 y posteriormente, en 1999, la Universidade do Sagrado Coracao, de Sao Paulo, Brasil lo editó en portugués (Os olhos do Imperio)

Es importante conocer y discutir una obra como Ojos imperiales, porque, además de regalarnos una reflexión sociohistórica tan fina, profunda y suspicaz como la apuntada, nos posibilita pensar el pensamiento. La manera en que han sido conocidas realidades contrastantes y diferentes a las propias, y cómo en ese humano problema que es el conocer y nombrar, la determinación política es capital. Adicionalmente a la reflexión epistemológica - pero no menos 
importante-, es necesario apuntar la actualidad de la problemática imperial, que Pratt analiza en sus orígenes decimonónicos y que se aprecia en cualquier noticiero de nuestros días, como parte de la retórica del neoimperialismo que ahora padecemos. ¿Con qué ojos, con qué voz, desde qué perspectiva de mundo describen los viajeros-reporteros de los medios de comunicación electrónica, las complejas y fascinantes realidades afganas, pakistaníes, palestinas, japonesas, coreanas...?

Mayabel Ranero Castro Facultad de Sociología, Universidad Veracruzana 